\title{
Foliar trichomes and their systematic relevance in Solanum (Solanaceae) species from southern Western Ghats, Kerala
}

\author{
V.S. Anil Kumar*, A.V. Sunila and K. Murugan \\ Plant Biochemistry and Molecular Biology Laboratory, Department of Botany, University College, \\ Thiruvananthapuram - 695034, Kerala, India. \\ *E-mail: vsanilbotany@gmail.com
}

\begin{abstract}
Morphological features of foliar trichomes have been successfully employed in classification of diverse groups of plants. The present study evaluates the taxonomic value of trichomes in 17 taxa of Solanum L. using Scanning Electron Microscopy. Both glandular and non-glandular trichomes were observed on the leaves which showed variations in their density of distribution among the species as well as on the two surfaces of the leaves of the same species. The non-glandular trichomes with 1 to 14 arms often form a dense mat over the leaf surfaces, providing protection. The differential length of the radiating arms also helpful in delimiting the species. The non-glandular trichomes are of two kinds: long and short capitate or ovate forms. Species with sparse nonglandular trichomes showed comparatively more number of glandular trichomes. The micromorphology and distribution patterns of trichomes can be used in the taxonomic delineation of various Solanum species.
\end{abstract}

Keywords: Adaptations, Glandular Hairs, Scanning Electron Microscopy, Stellate Hairs

\section{Introduction}

Plants are adapted to survive under different environmental conditions by morphological modifications. Aerial parts of the plants develop modifications when they are exposed to environmental stress. Trichomes and epidermal features are the main foliar adaptations in response to specific environments ( $\mathrm{Li}$ et al., 2011). Trichomes are the major morphological marker to analyze the interplay of various developmental events correlated with cellular functions (EdwinWosu et al., 2012). Celep et al. (2011) revealed the significance of trichome micromorphology of Lamium species. Trichome specificities effectively delineate taxa within genus or even at family level. Secretory and non-secretory trichomes provide insight on the nature of the secreted phytochemical and their defense against herbivores. Lamiaceae, Brassicaceae, Verbenaceae and Cucurbitaceae display glandular trichomes with potent bioactive molecules with immense economic importance. Hayat et al. (2009) and Dipa \& Daniel (2011) provided the significance of foliar trichomes in taxonomic discrimination in Acanthaceae and Artemisia in Asteraceae, respectively.
Solanaceae comprise 98 genera with $c$. 2700 species (Olmstead \& Bohs, 2007). The family includes many economically important vegetable species which are also employed as biological model systems. Adedeji et al. (2007) analyzed the organographic distribution of the trichomes of Solanaceae species and reported two types of trichomes, which showed variations among the species even within the same genus. Phylogeny of species in the family was traced by Sarkinen et al. (2013) in terms of phytochemistry, environmental niche, geographical distribution, ecological parameters and the genomes. Comparing other groups, the studies on trichome micromorphology of Solanum is scanty. Thus, the present study is an attempt to analyze the ultrastructural features of trichomes in Solanum using scanning electron microscopy and their ecological significance.

\section{Materials and Methods}

\section{Plant Materials}

Leaves of 17 taxa of Solanum, viz., S. americanum Mill., S. torvum Sw., S. violaceum (Ortega) subsp. violaceum, S. violaceum (Ortega) subsp. multiflorum (C.B. Clarke) K.M. Matthew, S. wendlandii Hook.f., 
S. macrocarpon L., S. melongena L. var. insanum (L.) Prain, S. erianthum D. Don, S. mauritianum Scop., S. giganteum Jacq., S. exarmatum Anil et al., S. capsicoides All., S. seaforthianum Andrews, S. mammosum L., S. aculeatissimum Jacq., S. pseudocapsicum L. and S. trilobatum L. were collected from Western Ghats of Kerala were subjected to Scanning Electron Microscopic examination, and the voucher specimens were later deposited at TBGT.

\section{Ultrastructural analysis using scanning electronic microscopy (SEM)}

The ultramorphological analysis was carried out using Scanning Electron Microscopy with healthy expanded leaf blades, fixed in 3\% glutaraldehyde. The samples were kept for $24 \mathrm{hrs}$ and subsequently washed in a $0.05 \mathrm{M}$ potassium phosphate buffer for 30 minutes. After that the leaf blades were dehydrated in ethyl alcohol series followed by critical point drying using $\mathrm{CO}^{2}$ (Bozzolla \& Russel, 1992) and mounted on metallic stubs. Further, the specimens are coated with gold in the Sputter coater (ION 25 SEM). Analysis was done using the scanning electron microscope (SU 6600, Hitachi and Zeiss EVO 18) and images were captured in different magnifications. A minimum of ten leaves per taxon have been analyzed and in all cases, fully expanded leaves are chosen. Very young and older leaves have been excluded from the analysis.

\section{Results and Discussion}

Leaves of Solanum species show wide range of variation in micromorphology in terms of distribution, nature and structure. Glandular and non-glandular trichomes were noticed in the Solanum species. The non-glandular trichomes may be stellate or simple while the glandular trichomes may be short or long-stalked. The number of arms in the stellate trichomes showed variations and similarly the number of cells in the stalk and head of the glandular trichomes also displayed variations among the species and sometimes on the two sides of the same leaf. Among the studied taxa, stellate trichomes are found in S. giganteum, S. erianthum, $S$. mauritianum, S. melongena var. insanum, S. violaceum subsp. multiflorum, S. violaceum subsp. violaceum and S. toroum (Fig. 1a-g). All these species also possess stellate non-glandular trichomes on both upper and lower surfaces of the leaves. However, density, number and nature of radiating arms show considerable variations among these taxa.
The number of radiating arms in most species is 9. Maximum number of radiating arms (up to 18) was observed in the pluricellular stellate trichomes of S. mauritianum (Fig. 1c). Solanum aculeatissimum is found to be distinct from the rest of the species in having stellate non-glandular trichomes along with simple trichomes on the lower surface (Fig. 1h).

The radiating arms of $S$. giganteum were broader and shorter under SEM (Fig. 1a). The stellate trichomes in S. violaceum subsp. violaceum were also comparatively shorter than all others (Fig. 1f). Solanum violaceum subsp. multiflorum is distinct from others in having single elongated slender pointed central arm in their stellate trichomes (Fig. 1e). In all other species with stellate trichomes, the slender radiating arms were more or less similar in size. The number of arms in stellate trichomes exhibit variations on both surfaces of the same leaves in the species investigated. In S. erianthum, the stellate trichomes on dorsal leaf surface have 1,3,4,5 and 8 arms (Fig. 2a), a feature not noticed in other species whilst those on lower surface have 8-10 arms (Fig. 1b). Similar stellate trichomes have been reported in S. leprosum (Toledo Picoli et al., 2013) and suggested that these differences are due to ontogenic processes starting at different times. In the present study, similar aged leaves of $S$. erianthum have been used, but the species showed the difference with respect to the number of arms in trichomes on the two surfaces. In $S$. mauritianum, the dorsal surface had 6-15 radiating arms for the stellate trichomes (Fig. 1c) and the lower leaf surface had mostly 6 arms (Fig. 2b). In S. melongena var. insanum (Fig. 1d) and S. giganteum (Fig. 1a), both the upper and lower surfaces of the leaves had stellate trichomes with 9 arms. It has been noted that in S. violaceum subsp. multiflorum, the stellate trichomes were having one much elongated slender pointed central arm with 3 basal protruding arms on the upper surface and with 8 basal protruding arms on the lower surface (Figs. 1e \& 2c). Interestingly, the elongated arms were found to have micropappillae or echinate ornamentations (Fig. 2d). According to Barthlott (1981) the cuticular micropappillae are in continuation of the cuticular folding present on the surface of the surrounding epidermal cells. Werker (2000) reported that the outer surface of the foliar trichomes in plants including members of Lamiaceae may be smooth or exhibit micro ornamentations such as micropappillae, warty, reticulate and seriate. In $S$. aculeatissimum, the lower leaf surface has stellate trichomes with 4 basal arms particularly along the veins and also has 

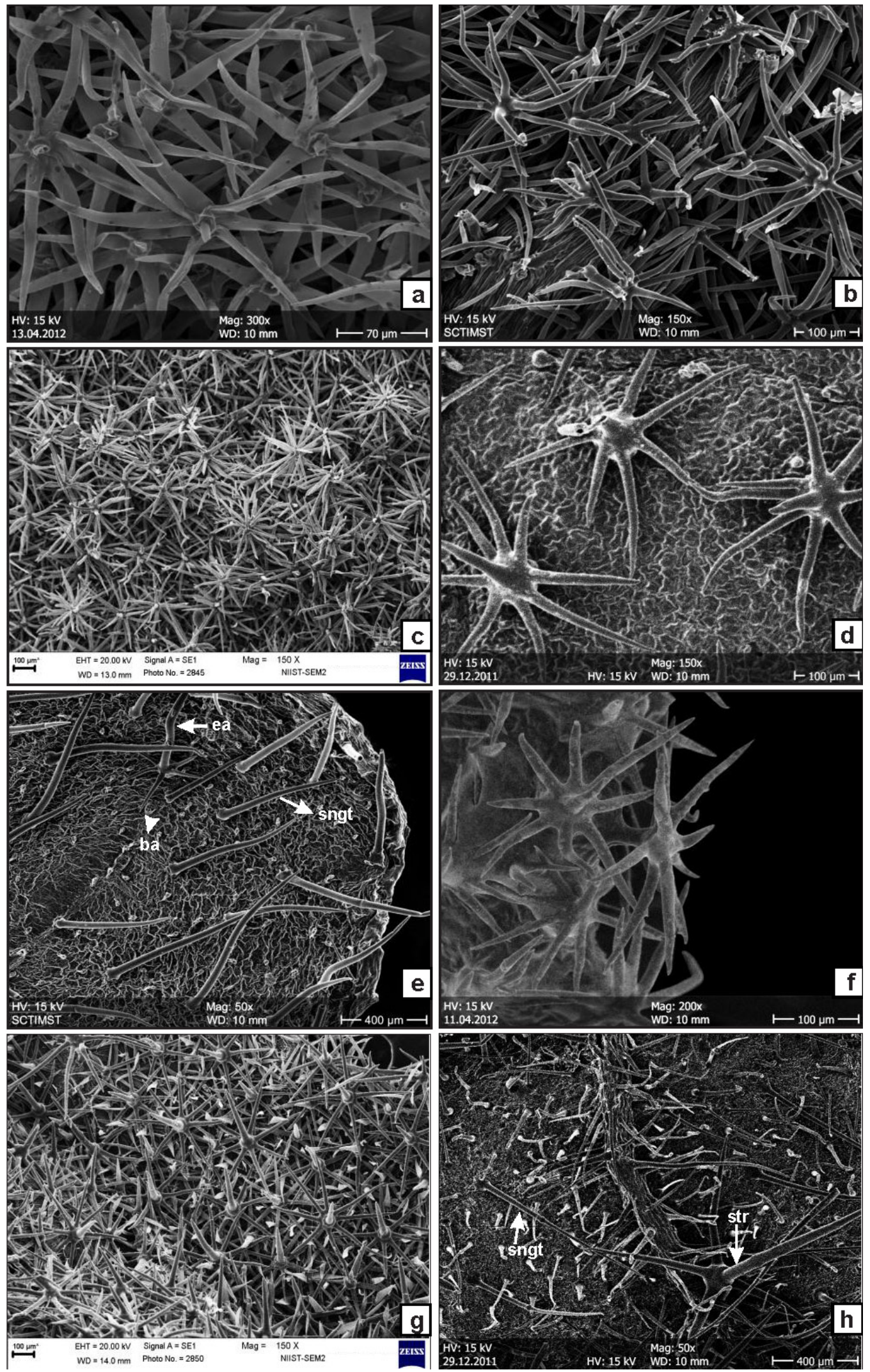

Fig. 1. Non-glandular trichomes of Solanum taxa: a. Upper leaf surface of $S$. giganteum Jacq.; b. Lower leaf surface of S. erianthum D. Don.; c. Upper leaf surface of S. mauritianum Scop.; d. Upper leaf surface of S. melongena (L.) var. insanum (L.) Prain; e. Upper leaf surface of S. violaceum Ortega subsp. multiflorum (C.B. Clarke) K.M. Matthew; f. Upper leaf surface of S. violaceum Ortega subsp. violaceum; g. Upper leaf surface of S. torvum Sw.; h. Lower leaf surface of $S$. aculeatissimum Jacq. 

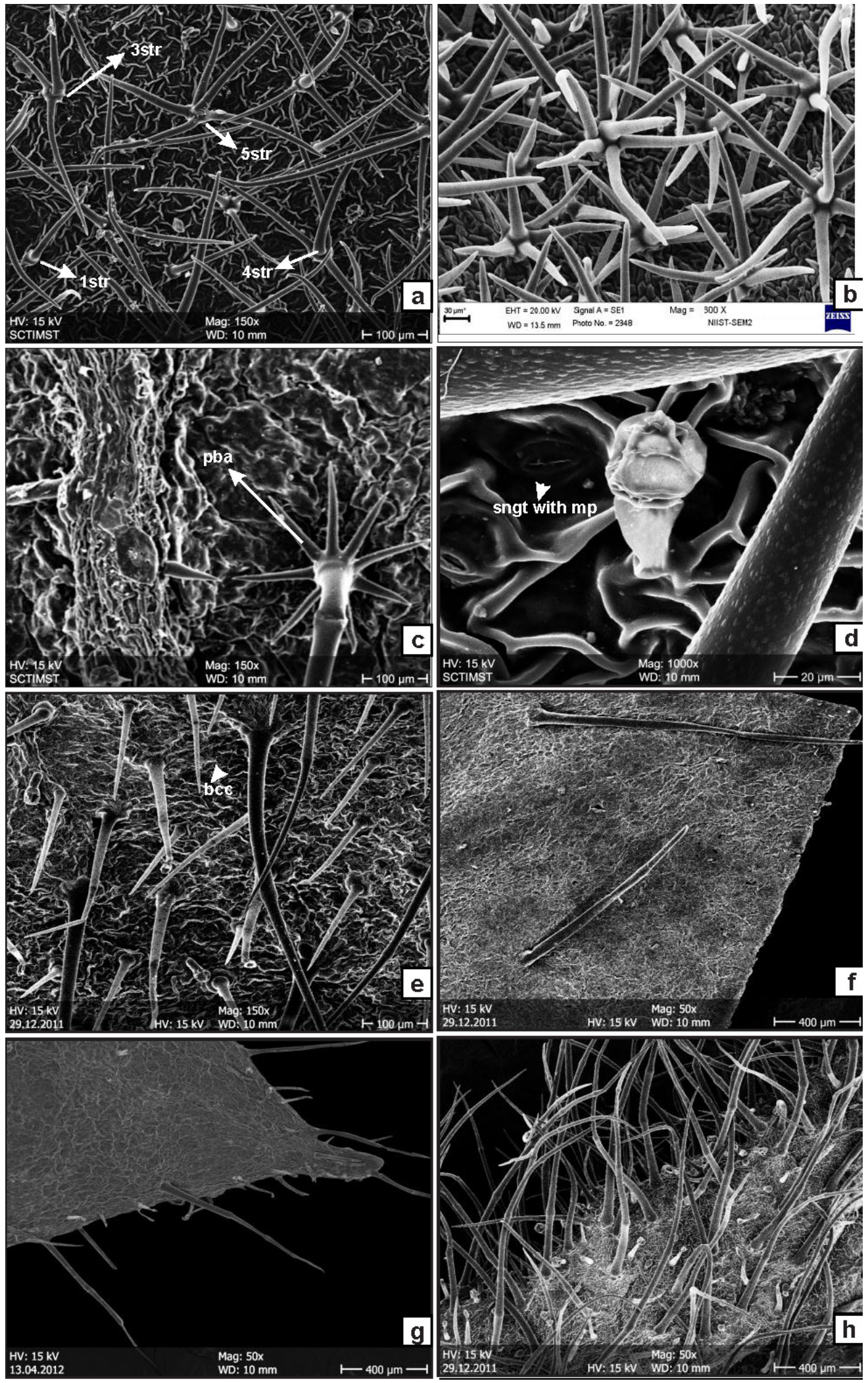

Fig. 2. Non-glandular trichomes of Solanum taxa: a. Upper leaf surface of $S$. erianthum D. Don.; b. Lower leaf surface of S. mauritianum Scop.; c. Lower leaf surface of S. violaceum Ortega subsp. multiflorum (C.B. Clarke) K.M. Matthew; d. Micropapillate projections on the trichomes $S$. violaceum Ortega subsp. multiflorum (C.B. Clarke) K.M. Matthew.; e. Simple non-glandular trichomes on the upper leaf surface of $S$. aculeatissimum Jacq.; $f, g$. Simple trichomes on the upper leaf surface of S. capsicoides All. and S. exarmatum Anil et al.; h. Upper leaf surface of S. mammosum L. 
simple non-glandular trichomes along the veins and leaf surface (Fig. 1h). The simple trichomes are mostly two-celled. The upper surface of the leaf bears only two-celled simple trichomes with basal cluster of short cells (Fig. 2e).

Species such as S. capsicoides, S. exarmatum (Fig. 2f,g), and S. mammosum (Fig. 2h) have simple non-glandular trichomes. These simple trichomes form dense mat-like covering over the leaf surface in S. mammosum (Fig. 3a). Among the studied taxa, S. mauritianum and S. toroum are having comparatively denser distribution of stellate trichomes as thick mat over the upper leaf surface (Fig. 1c,g). This can be correlated with the specific habitat of Solanum species. Hairy leaves reduce leaf internal temperatures and transpiration (Sandquist \& Ehleringer, 2003) whilst inter- and intra-specific variations exist for this feature. There are previous reports regarding the functioning of leaf trichome density as a defensive trait against herbivory among solanaceous species (van Dam \& Hare, 1998). In S. giganteum, the leaves are covered with stellate trichomes all over the surface (Fig. 1a). In S. erianthum, the lower surface of the leaves has denser distribution of stellate trichomes rather than the upper surface (Figs. 1b \& 2a). Hussain et al. (1990) reported that in most of the plant species, trichomes are much denser on the lower surface which tends to diminish the importance of trichomes as a sunshade adaptation. However, based on the stomatal studies conducted on Solanum species (Anil Kumar et al., 2013), it can be inferred that the lower surface of the leaves is having more stomatal frequency (Table 1). The leaf morphological and physiological attributes change with different environmental conditions appear to be consequence of responses to abiotic factors such as soil moisture (Beerling et al., 1996; Sun et al., 1996), air temperature (Panek \& Waring, 1995), and atmospheric $\mathrm{CO}^{2}$ levels (Marshall \& Monserud, 1996). For the present investigation, all the specimens have been collected from plants growing in their natural habitats and also in the same season and hence the influence of environmental variations can be neglected in considering trichome morphology as a speciesspecific trait.

Solanum pseudocapsicum and S. trilobatum lack non-glandular trichomes on either surface of the leaves (Fig. 3b,c). This may be due to the relatively low stomatal indices in the taxa (Table 1). In S. americanum, multicellular non-glandular trichomes with broad base are scattered on the upper surface and margins of leaves (Fig. 3d), and are also studded with micropappillae. In $S$. seaforthianum, similar type and distribution of nonglandular trichomes could be observed, though the nature of glandular trichomes is different from that of S. americanum (Fig. 3e). Solanum macrocarpon has slender elongated non-glandular trichomes together with glandular trichomes on leaf margins (Fig. 3f), but surfaces of the leaves are devoid of any non-glandular trichomes. Solanum wendlandii has non-glandular trichomes with broad base only on the leaf margins (Fig. $3 \mathrm{~g}$ ). All these species are not having the protective mat of stellate trichomes. Solanum trilobatum, $S$. macrocarpon and $S$. wendlandii are having reflective cuticular layer on the upper surface of their leaves. This feature of glaucousness or waxy bloom on leaves is a boon to maintain high tissue water potential and is therefore considered as desirable trait for drought tolerance (Ludlow \& Muchow, 1990). Richards et al. (1986) compared the range of leaf temperature between non-glaucous and glaucous leaves of Triticum and also the rate of leaf senescence. They observed that glaucous leaves were retained longer than non-glaucous leaves in the droughted treatment. Further, S. trilobatum and S. macrocarpon showed comparatively low stomatal indices. It may be because their leaves lack dense trichome mat to protect from excess transpiration. However, comparatively higher stomatal frequencies have been noticed with the lower surface of $S$. wendlandii and both surfaces of $S$. seaforthianum. Both these species are without trichome mat and it can be suggested that the habit as well as habitat of these species may be the reason for these variations. Apart from the role of glaucous layer, some additional physiological mechanisms may be operating in the xeric plants like Opuntia (Nerd \& Nobel, 1991), and others. This include decline in turgor potential due to water loss from the water storage parenchyma. However, the physiology related to the water stress and glaucousness in Solanum species needs further studies. It has been reported that plants generally limit the number and area of leaves in response to drought stress to reduce the water budget at the cost of yield loss (Schuppler et al., 1998). In S. wendlandii and S. seaforthianum, the leaf area is reduced owing to the dissected nature of leaves. As far as S. americanum is concerned, the species exclusively prefers moist shady habitats with low light and temperature exposure.

Another important strategy of glandular trichome is related with its chemical defense against herbivores (Ascensao et al., 1999) and nonglandular trichomes in mechanical defense and protect the plants from excessive transpiration 

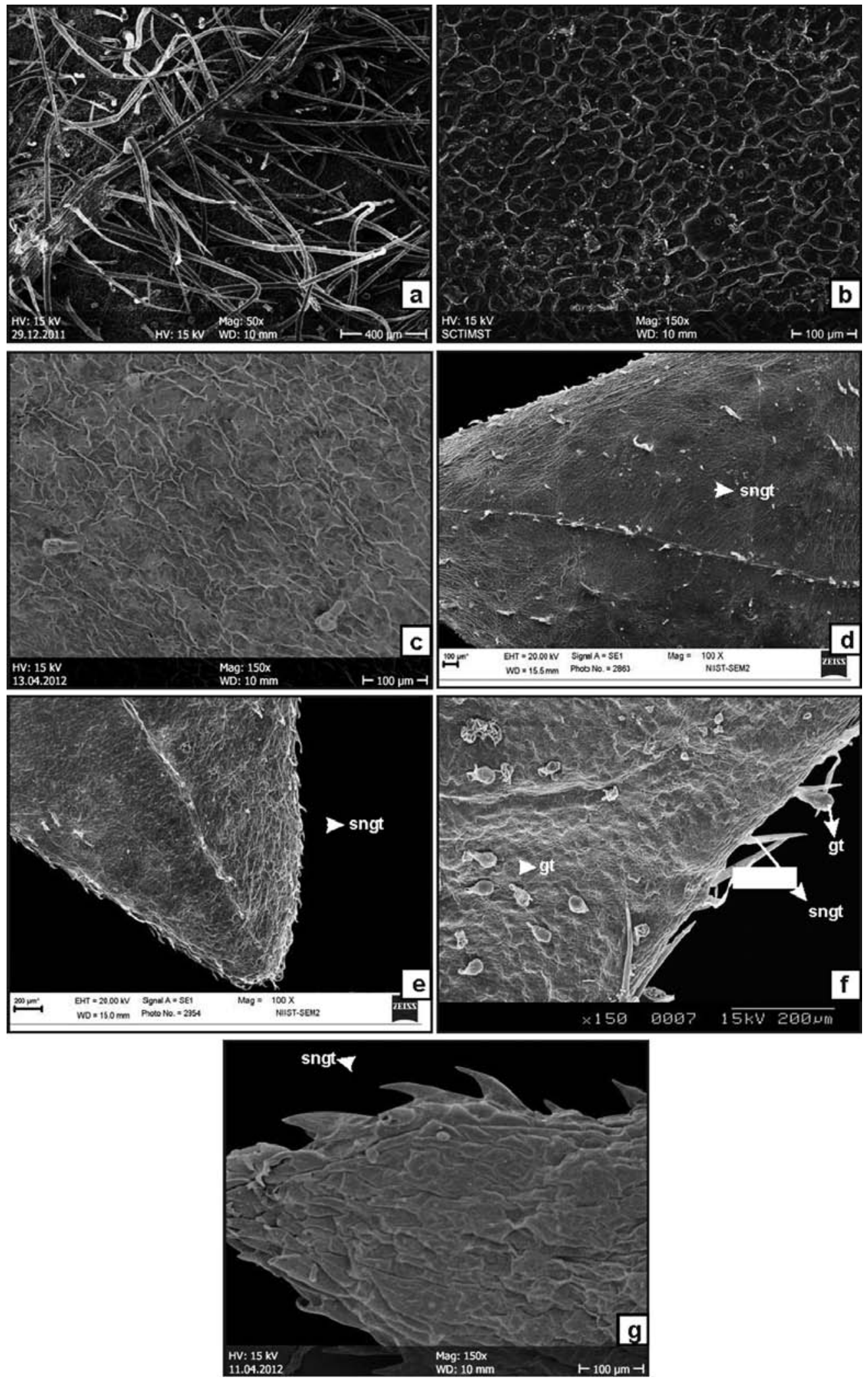

Fig. 3. Non-glandular trichomes of Solanum species: a. Dense simple trichomes on the lower leaf surface of S. mammosum L.; b. Upper leaf surface of S. pseudocapsicum L.; c. Upper leaf surface of S. trilobatum L.; d. Scattered non-glandular trichomes on the upper leaf surface of $S$. americanum Mill.; e. Upper leaf surface of $S$. seaforthianum Anderws showing scattered nonglandular trichomes; f. S. macrocarpon L. showing leaf margin with glandular and non-glandular trichomes; g. Broad based non-glandular trichomes on the upper leaf surface of $S$. wendlandii Hook.f. 
Table 1. Stomatal indices of Solanum taxa

\begin{tabular}{|c|c|c|c|}
\hline \multirow[t]{2}{*}{ S1. No. } & \multirow[t]{2}{*}{ Taxa Studied } & \multicolumn{2}{|c|}{ Stomatal Index* } \\
\hline & & Upper Epidermis & Lower Epidermis \\
\hline 1. & Solanum aculeatissimum Jacq. & $3.92^{\mathrm{h}}$ & $8.44^{\mathrm{k}}$ \\
\hline 2. & Solanum americanum Mill. & $11.71^{\mathrm{c}}$ & $24.47^{\mathrm{d}}$ \\
\hline 3. & Solanum capsicoides All. & $13.7^{\mathrm{b}}$ & $18.01^{\mathrm{g}}$ \\
\hline 4. & Solanum erianthum D. Don & $10.93^{\mathrm{d}}$ & $26.67^{b}$ \\
\hline 5. & Solanum exarmatum Anil et al. & $5.46^{\mathrm{f}}$ & $12.25^{\mathrm{i}}$ \\
\hline 6. & Solanum giganteum Jacq. & $5.37^{\mathrm{f}}$ & $18.75^{\mathrm{g}}$ \\
\hline 7. & Solanum macrocarpon $\mathrm{L}$. & $3.92^{\mathrm{h}}$ & $6.2^{1}$ \\
\hline 8. & Solanum mammosum L. & $13.67^{\mathrm{b}}$ & $25.17^{c}$ \\
\hline 9. & Solanum mauritianum Scop. & $4.44^{\mathrm{g}}$ & $22.94^{\mathrm{e}}$ \\
\hline 10. & Solanum melongena L. var. insanum (L.) Prain & $6.0^{\mathrm{e}}$ & $13.37^{\mathrm{h}}$ \\
\hline 11. & Solanum pseudocapsicum L. & $2.77^{\mathrm{i}}$ & $4.59^{\mathrm{m}}$ \\
\hline 12. & Solanum seaforthianum Andrews & $21.51^{\mathrm{a}}$ & $33.88^{\mathrm{a}}$ \\
\hline 13. & Solanum torvum Sw. & $1.02^{j}$ & $12.76^{\mathrm{i}}$ \\
\hline 14. & Solanum trilobatum L. & $6.45^{\mathrm{e}}$ & $10.15^{j}$ \\
\hline 15. & $\begin{array}{l}\text { Solanum violaceum Ortega subsp. multiflorum } \\
\text { (C.B. Clarke) K.M. Matthew }\end{array}$ & $5.37^{\mathrm{f}}$ & $13.96^{\mathrm{h}}$ \\
\hline 16. & Solanum violaceum Ortega subsp. violaceum & $3.05^{\mathrm{h}}$ & $13.48^{\mathrm{h}}$ \\
\hline 17. & Solanum wendlandii Hook.f. & $5.69^{f}$ & $20.02^{\mathrm{f}}$ \\
\hline
\end{tabular}

* Mean values followed by the same letter in the superscript do not vary significantly based on ANOVA and $\mathrm{t}$-test at $\mathrm{p} \leq 0.05$.

(Corsi \& Bottega, 1999). The glandular trichomes vary in morphology, structure and in number per unit area of the epidermis among species and organs (Ascensao et al., 1999). In Solanum, the glandular trichomes on leaves generally belong to two groups, viz., long and short capitate or ovoid glandular trichomes as observed in S. capsicoides, S. exarmatum, S. erianthum, S. aculeatissimum, S. giganteum, S. macrocarpon, S. mauritianum, S. melongena var. insanum, S. violaceum subsp. multiflorum, S. pseudocapsicum, S. trilobatum, S. torvum, S. violaceum subsp. violaceum, S. mammosum and $S$. wendlandii (Figs. $\mathbf{4} \mathbf{a}-\mathbf{h} \& \mathbf{5} \mathbf{a}-\mathbf{g}$ ). In $S$. seaforthianum, the heads of glandular trichomes are conical with pointed tips on multicellular long stalk whilst in S. americanum, the heads are elongated ovoid with blunt tips (Fig. 5 h,i). The long-glandular trichomes in S. capsicoides and $S$. exarmatum have globular secreting heads and in S. aculeatissimum, these long-glandular trichomes have ovoid heads (Fig. $\mathbf{4 a}, \mathbf{b}, \mathbf{d}$ ). Presence of glandular trichomes is characteristic of the genus Solanum and other members of Solanaceae with the exception of Nicotiana glauca and Solandra nitida (Maiti et al., 2002). These types of glandular trichomes identified on the leaves might be responsible for the production, accumulation and release of secondary metabolites such as saponins and steroid alkaloids as reported by Drewes \& van Staden (1995). The secondary metabolites secreted from the glandular trichomes of aerial organs are related to defense of plants against the attack of herbivores and pathogens or act as attractants to pollinators or for fruit dispersal (Werker et al., 1994; Heinrich et al., 2002). Like the non-glandular trichomes, the glandular trichomes also show variation in their density and distribution pattern.

In the present investigation, S. aculeatissimum, S. capsicoides, S. exarmatum and S. mammosum display the presence of glandular trichomes on both surfaces of leaves. Meanwhile, it is restricted to upper surface of the leaves in others, viz., S. erianthum, S. giganteum, S. macrocarpon, S. mauritianum, S. melongena var. insanum, S. pseudocapsicum, S. seaforthianum, S. violaceum subsp. violaceum, S. 

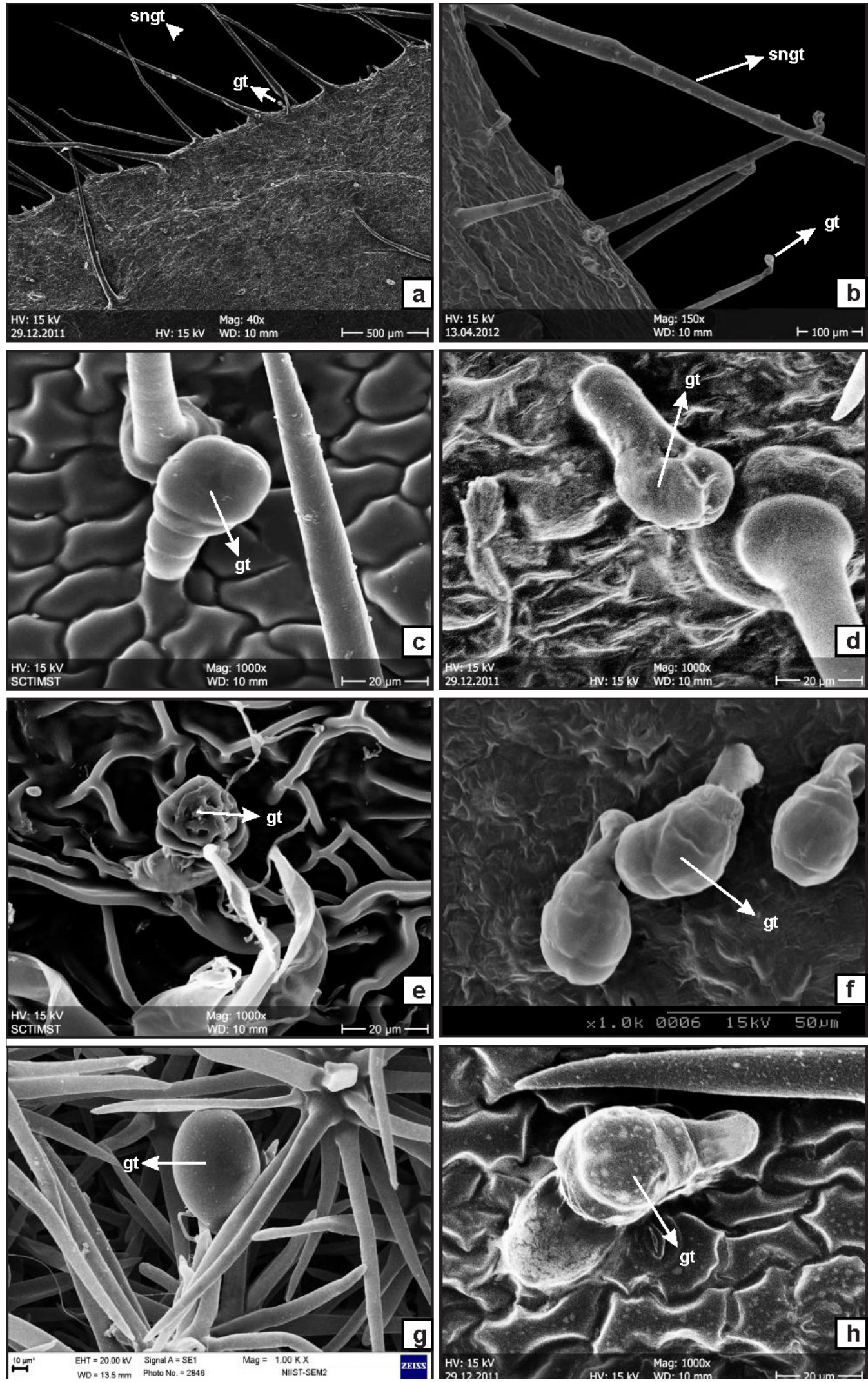

Fig. 4. Glandular trichomes of Solanum taxa: a. Upper leaf surface of S. capsicoides All.; b. Upper leaf surface of S. exarmatum Anil et al.; c. Upper leaf surface of $S$. erianthum D. Don.; d. Upper leaf surface of $S$. aculeatissimum Jacq.; e. Upper leaf surface of S. giganteum Jacq.; f. Upper leaf surface of S. macrocarpon L.; g. Upper leaf surface of S. mauritianum Scop.; $h$. Upper leaf surface of S. melongena (L.) var. insanum (L.) Prain. 

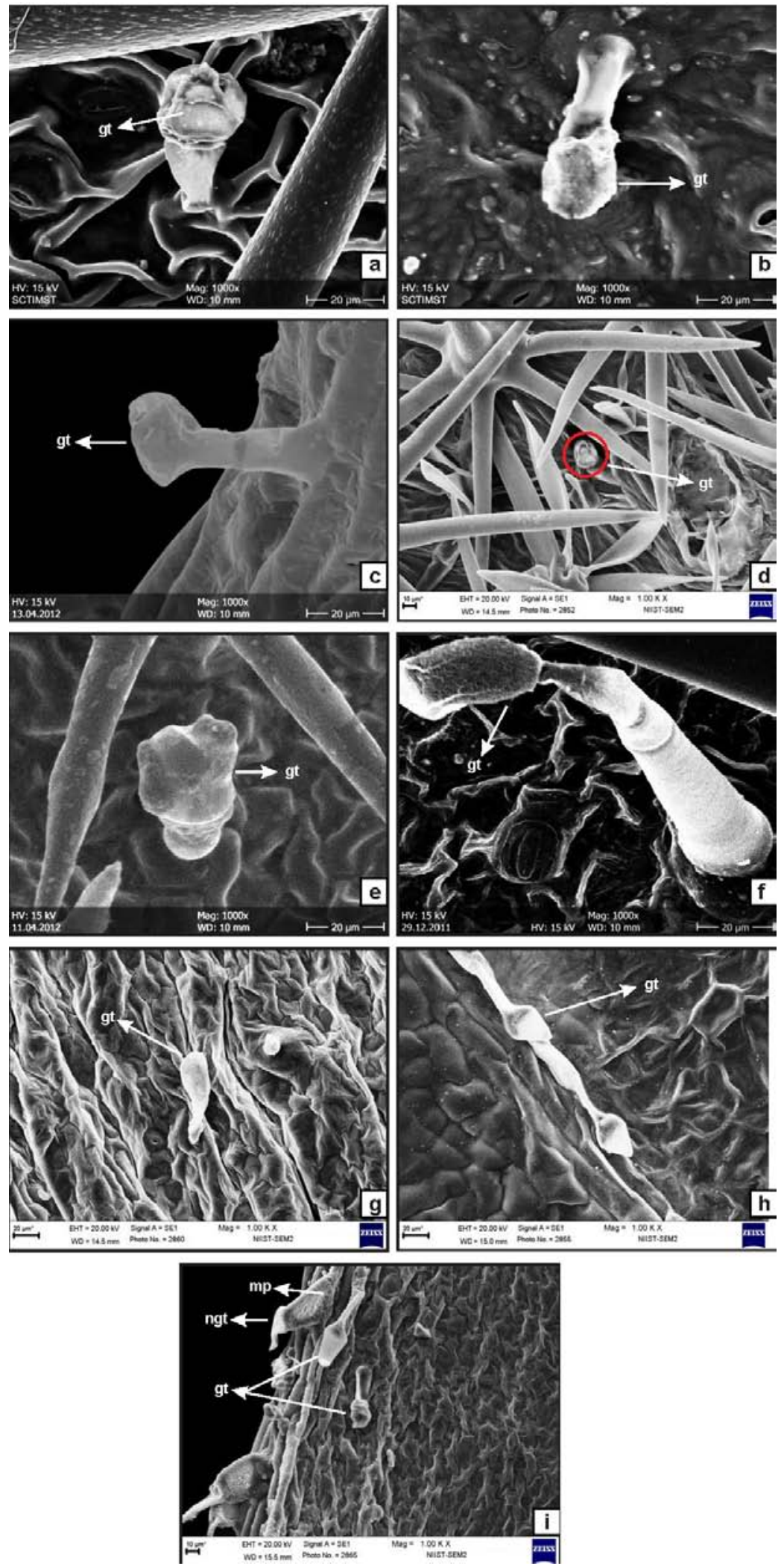

Fig. 5. Glandular trichomes of Solanum taxa: a. Upper leaf surface of S. violaceum Ortega subsp. multiflorum (C.B. Clarke) K.M. Matthew; b. Upper leaf surface of S. pseudocapsicum L.; c. Upper leaf surface of S. trilobatum L.; d. Upper leaf surface of $S$. torvum Sw.; e. Upper leaf surface of $S$. violaceum Ortega subsp. violaceum; f. Lower leaf surface of S. mammosum L.; g. upper leaf surface of $S$. wendlandii Hook.f.; h. Upper leaf surface of $S$. seaforthianum Andrews; i. Upper leaf surface of S. americanum Mill. 
trilobatum, S. macrocarpon, S. americanum and S. wendlandii. Further, a few scattered glandular trichomes are noticed on the lower surface of $S$. trilobatum and S. wendlandii (Fig. 5c,g). Solanum wendlandii possesses non-glandular trichomes with broad base along the leaf margins but $S$. trilobatum lacks such non-glandular trichomes. In S. americanum, the glandular trichomes are also found along the margins. Solanum macrocarpon, $S$. pseudocapsicum and S. seaforthianum lack both nonglandular or glandular trichomes on their lower leaf surface.

Leaves of Solanum species having dense mat of stellate trichomes display reduced number of glandular trichomes and this dense mat of stellate trichomes functions as bioshield against the stresses. On other hand, species with sparse stellate or simple non-glandular trichomes showed more number of glandular trichomes. This can be considered as an acquired defense adaptation of the species to escape from pathogenic invasion as these glandular trichomes have the potential to secrete bioactive defense compounds (Wagner et al., 2004). A striking observation noticed in the present study is that spiny Solanum taxa are having an equidistribution of glandular and nonglandular trichomes, except $S$. trilobatum. The species without spines namely $S$. mauritianum and S. erianthum have comparatively low density of glandular trichomes amidst the mat of stellate trichomes which take part in the defense role. The exact phylogeny behind these kinds of adaptive responses is yet to be unraveled.

In the investigated species namely $S$. giganteum, S. melongena var. insanum, S. violaceum subsp. multiflorum, S. torvum, S. violaceum subsp. violaceum and $S$. wendlandii are having peltate glandular trichomes on the upper surface of their leaves, though the density of distribution varied drastically (Figs. 4e,h \& 5a,d,e,g). Only a scanty number of such trichomes could be observed with S. torvum. In S. mauritianum, ovoid glandular trichomes were observed in lesser density on the upper surface (Fig. $\mathbf{4 g}$ ). Solanum violaceum subsp. violaceum is different from rest of the species in having peltate glandular trichomes on the lower surface of the leaves also. Interestingly, the stellate non-glandular trichomes are abundant on both surfaces and the rays of adjacent trichomes interlock and form a dense cover and often form two or three layers of flattened multicellular shields. Though ecological variations may affect the distribution of trichomes, the type of trichome is constant in most species (Okpon, 1969). Many researchers have employed the presence or absence and types of trichomes on the epidermal surfaces as key characters for classification (Rollins \& Shaw, 1973; Adedeji et al., 2007). It has long been suggested that the types of epidermal trichomes can frequently be used in delimiting species, genera or families (Hayat et al., 2009; Shaheen et al., 2009; Ajmal Ali \& Al Hemaid, 2010; Saheed \& Illoh, 2010; Kemka \& Nwachukwu, 2011; Adedeji, 2012; Al Sheef et al., 2013; Khan et al., 2013; Rashid \& Parnell, 2013; Naidoo et al., 2014). The following key has been constructed to easily differentiate the 17 different Solanum taxa found in the southern Western Ghats, Kerala based on the type and distribution of trichomes observed on their leaf surfaces during the present Scanning Electron Microscopic study.

\section{Key to taxa}

1. Non-glandular and glandular trichomes present 2

1. Non-glandular trichomes absent but glandular trichomes present 16

2. Presence of either simple or stellate nonglandular trichomes 3

2. Presence of both simple and stellate nonglandular trichomes . 15

3. Trichomes of exclusively stellate 4

3. Trichomes of exclusively simple ...................... 9

4. Dense mat of trichomes present ....................... 5

4. Dense mat of trichomes absent 8

5. Radiating arms of trichomes shorter, broader and equal-sized S. giganteum

5. Radiating arms of trichomes are slender and equal-sized 6

6. Glandular trichomes with multicellular stalks S. erianthum

6. Glandular trichomes with unicellular stalks .. 7

7. Stellate trichomes on dorsal surface with up to 18 radiating arms S. mauritianum

7. Stellate trichomes on dorsal surface with up to 9 radiating arms S. torvum

8.... Peltate glandular trichomes present on abaxial and adaxial leaf surfaces

S. violaceum subsp. violaceum

8. Peltate glandular trichomes present on adaxial leaf surface only .. S. melongena var. insanum

9. Leaves with glandular trichomes on both surfaces 10 
9. Leaves with glandular trichomes on dorsal surface only 12

10. Secretory heads of glandular trichomes multicellular and elongated .... S. mammosum

10. Secretory heads of glandular trichomes singlecelled and globular 11

11. Leaves with long-glandular trichomes amidst short-stalked ones S. capsicoides

11. Leaves with long-glandular trichomes only S. exarmatum

12. Margins as well as leaf surfaces with glandular trichomes 13

12. Margins lack glandular trichomes and are confined to leaf blade 14

13. Non-glandular trichomes seen amidst glandular ones are with micropappillae S. americanum

13. Non-glandular trichomes seen amidst glandular ones are without micropappillae......

S. macrocarpon

14. Stalks of secretory trichomes long slender with conical pointed secretory sacs

S. seaforthianum

14. Stalks of secretory trichomes shorter with ovoid secretory sacs having blunt tips

S. wendlandii

15. Simple and stellate trichomes interspersed and the stellate trichomes studded with micropappillae with one of the arms much longer …......S. violaceum subsp. multiflorum

15. Simple and stellate trichomes interspersed on lower surface; arms of stellate trichomes have equal length without micropappillae

S. aculeatissimum

16. Short-stalked glandular trichomes have peltate head S. trilobatum

16. Short stalked-glandular trichomes have ovoid head S. pseudocapsicum

\section{Conclusion}

The trichome morphology of Solanum species and distribution pattern of trichomes on leaf surfaces are useful in distinguishing the species. Particularly, this would be helpful for pharmacognosists, archaeobotanists, paleobotanists and agronomists. Occurrence of diverse glandular or non-glandular trichomes reported in the present study reflects the foliar features of studied Solanum taxa.

\section{Acknowledgements}

The authors would like to express their sincere gratitude to the Directors of National Institute for Interdisciplinary Science and Technology and Sree Chitra Tirunal Institute for Medical Sciences and Technology, Thiruvananthapuram, for providing the SEM facilities. The help rendered by Dr. Maya C. Nair, Department of Botany, Govt. Victoria College, Palakkad in interpretation of keys and the tribal as well as local people of various districts of the state, for their assistance in collection of specimens are greatly acknowledged.

\section{Literature Cited}

Adedeji, O. 2012. Systematic significance of trichomes and foliar epidermal morphology in the species of Stachytarpheta Vahl (Verbenaceae) from Nigeria. Thaiszia 22(1): 1-31.

Adedeji, O., Ajuwon, O.Y. \& O. Babawale 2007. Foliar epidermal studies, organographic distribution and taxonomic importance of trichomes in the family Solanaceae. Int. J. Bot. 3(3): 276-282.

Ajmal Ali, M. \& F.M.A. Al-Hemaid 2011. Taxonomic significance of trichome micromorphology in cucurbits. Saudi J. Biol. Sci. 18: 87-92.

Al Sheef, N.B., Duletić-Laušević, S.N., Janošević, D., Budimir S.M., Marin, M., Alimpić, A., Giweli, A.A.M. \& P.D. Marin 2013. Micromorphology and ultrastructure of trichomes of Libyan Salvia fruticosa Mill. Arch. Biol. Sci. Belgrade 65(1): 239-248.

Anil Kumar, V.S., Sruthy, S.P. \& K. Murugan 2013. Foliar fingerprinting of Solanum species from Kerala. Phytomorphology 63(1\&2): 45-55.

Ascensao, L., Mota, L., De, M. \& M. Castro 1999. Glandular trichomes on the leaves and flowers of Plectranthus ornatus: Morphology, distribution and histochemistry. Ann. Bot. 84: 437-447.

Barthlott, W. 1981. Epidermal and seed surface characters of plants: Systematic applicability and some evolutionary aspects. Nordic J. Bot. 1: 345-355.

Beerling, D.J., Heath, J., Woodward, F.I. \& T.A. Mansfield 1996. Drought- $\mathrm{CO}_{2}$ interactions in trees: observations and mechanisms. New Phytol. 134: 235-242.

Bozzolla, J.J. \& L.D. Russel 1992. Electron Microscopy. First Edition. Jones \& Bartlett Publishers, Boston. 
Celep, F., Kahraman, A., Atalay, Z. \& M. Dogan 2011. Morphology, anatomy and trichome properties of Lamium truncatum Boiss. (Lamiaceae) and their systematic implications Austral. J. Crop Sci. 5(2): 147-153.

Corsi, G. \& S. Bottega 1999. Glandular hairs of Salvia officinalis: New data on morphology, localization and histochemistry in relation to function. Ann. Bot. 84: 657-664.

Dipa, C. \& M. Daniel 2011. Foliar trichomes of some members of the family Acanthaceae and their taxonomic utility. Int. J. Pharm. Biol. Sci. 2(3): 231-235.

Drewes, F.E. \& J. Van Staden 1995. Aspects of the extraction and purification of solasodine from Solanum aculeastrum tissues. Phytochem. Anal. 6: 203-206.

Edwin-Wosu, L., Nsirim., Wejinya, C. \& T. Omara-Achong 2012. Biosystematic studies in the Loganiaceae (Series 1): Foliar trichome morphology of tree species of Anthocleista Afzel Found in Parts of the Niger Delta, Nigeria. Eur. J. Exp. Biol. 2(6): 1988-2000.

Hayat, M.Q., Asraf, M., Khan, M.A., Yasmin, G., Shaheen, N.\&S. Jabeen 2009. Diversity of foliar trichomes and their systematic implications in the genus Artemisia (Asteraceae). Int. J. Agric. Biol. 11(5): 542-546.

Heinrich, G., Pfeifhofer, H.W., Stabentheiner, E. \& T. Sawidis 2002. Glandular hairs of Sigesbeckia jorullensis Kunth (Asteraceae): morphology, histochemistry and composition of essential oil. Ann. Bot. 88: 459-469.

Husain, S.Z., Marin, P.D., Šiliæ, È., Qaiser, M. \& B. Petcoviæ 1990. A micromorphological study of some representative genera in the tribe Saturejeae (Lamiaceae). Bot. J. Linn. Soc. 103: $59-80$.

Kemka, C.I. \& C.U. Nwachukwu 2011. Epidermal micromorphology of species in the genus Crasocephalum Moench. S. More (Compositae) in Nigeria. J. Pharm. Clin. Sci. 3: 31-41.

Khan, G., Zhang, F., Gao, Q., Mazhwani, Z.R., Rehman, K., Ajab Khan, M. \& S. Chen 2013. Trichome diversity in tropical flora of Pakistan. J. Med. Pl. Res. 7(22): 1587-1592.

Li, Z., Chen, Y., Li, W. \& Z. Wang 2011. Anatomical and morphological characteristics of Populus euphratica in the lower reaches of Tarim River under extreme drought environment. J. Arid Land 3(4): 261-267.
Ludlow, M.M. \& R.C. Muchow 1990. A critical evaluation of traits for improving crop yields in water-limited environments. Advances Agron. 43: 107-153.

Maiti, R.K., Villarreal, L.R., Trevino, A.V. \& M.C. Vallades-Cerda 2002. Some aspects on pharmacognosy of ten species of the family Solanaceae utilized in traditional medicine. Caldasia 24: 317-321.

Marshall, J.D. \& R.A. Monserud 1996. Homeostatic gas exchange parameters inferred from $13 \mathrm{C} / 12 \mathrm{C}$ in tree rings of conifers. Oecologia 105: 13-21.

Naidoo, Y., Heneidak, S., Bhatt, A., Kasim, N. \& G. Naidoo 2014. Morphology, histochemistry, and ultrastructure of foliar mucilage-producing trichomes of Harpagophytum procumbens (Pedaliaceae). Turk. J. Bot. 38: 60-67.

Nerd, A. \& P.S. Nobel 1991. Effects of drought on water relations and nonstructural carbohydrates in cladodes of Opuntia ficusindica. Physiol. Pl. 81: 495-500.

Okpon, E.N.U. 1969. Morphological notes on the genus Cassia: I. Notes Roy. Bot. Gard. Edinburgh 29: 185-195.

Olmstead, R.G. \& L. Bohs 2007. A summary of molecular systematic research in Solanaceae: 1982-2006. Acta Hort. 745: 255-268.

Panek, J.A. \& R.H. Waring 1995. Carbon isotope variation in Douglas-fir foliage: improving the ${ }^{\delta 13} \mathrm{C}$, climate relationship. Tree Physiol. 15: 657-663.

Rashid, M.H. \& J. Parnell 2013. Foliar micromorphological studies in some species of Premna L. (Lamiaceae) and their taxonomic implications. Pleione 7(2): 333-345.

Richards, R.A., Rawson, H.M. \& D.A. Johnson 1986. Glaucousness in wheat: its development, and effect on water-use efficiency, gas exchange and photosynthetic tissue temperatures. Austral. J. Pl. Physiol. 13: 465-473.

Rollins, R.C. \& E.A. Shaw 1973. The genus Lesquerella (Cruciferae) in North America. Harvard University Press, Cambridge.

Rusydi, A., Talip, N., Latip, J., Abdul Rahman, R. \& I. Sharif 2013. Morphology of trichomes in Pogostemon cablin Benth. (Lamiaceae). Austral. J. Crop Sci. 7(6): 744-749.

Saheed, S.A. \& H.C. Illoh 2010. A taxonomic study of some species in Cassiinae (Leguminosae) 
using leaf epidermal characters. Notul. Bot. Horti Agrobot.Cluj-Napoca 38(1): 21-27.

Sandquist, D.R. \& J.R. Ehleringer 2003. Population- and family-level variation of brittle bush (Encelia farinosa, Asteraceae) pubescence: its relation to drought and implications for selection in variable environments. Amer. J. Bot. 90: 1481-1486.

Sarkinen, T., Bohs, L., Olmstead, R.G. \& S. Knapp 2013. A phylogenetic framework for evolutionary study of the nightshades (Solanaceae): a dated 1000-tip tree. BMC Evol. Biol. 13: 214-238.

Schuppler, U., He, P.H., John, P.C.L. \& R. Munns 1998. Effects of water stress on cell division and cell-division-cycle-2-like cell-cycle kinase activity in wheat leaves. Pl. Physiol. 117: 667678.

Shaheen, N., Ajab, M., Yasmin, G. \& M.Q. Hayat 2009. Diversity of foliar trichomes and their systematic relevance in the genus Hibiscus (Malvaceae). Int. J. Agric. Biol. 11(3): 279-284.

Sun, Z.J., Livingston, N.J., Guy, R.D. \& G.J. Ethier 1996. Stable carbon isotopes as indicators of increased water use efficiency and productivity in white spruce [Picea glauca (Moench) Voss] seedlings. Pl. Cell Environm. 19: 887-894.
Toledo Picoli, E.A. de, Santos Isaias, R.M. dos, Ventrella, M.C. \& R.M. de Miranda 2013. Anatomy, histochemistry and micromorphology of leaves of Solanum granuloso-leprosum Dunal. Biosci. J. Uberlândia 29(3): 655-666.

van Dam, N.M. \& J.D. Hare 1998. Differences in distribution and performance of two sap-sucking herbivores on glandular and nonglandular Datura wrightii. Ecol. Entomol. 23: 22-32.

Wagner, G.J., Wang, E. \& R.W. Sheperd 2004. New approaches for studying and exploiting an old protuberance, the plant trichome. Ann. Bot. 93: 3-11.

Werker, E. 2000. Trichome diversity and development. Advances Bot. Res. 31: 1-35.

Werker, E., Putievsky, E., Ravid, U., Dudai, N. \& I. Katzir 1994. Glandular hairs, secretory cavities, and the essential oil in leaves of tarragon (Artemisia dracunculus L.). J. Herbs Spices Med. Pl. 2: 19-32.

Received: 28.6.2017

Revised and Accepted: 4.12.2017 